\title{
Bird communities in a degraded forest biodiversity hotspot of East Africa
}

\author{
Moses Mulwa ${ }^{1} \cdot$ Mike Teucher $^{2} \cdot$ Werner Ulrich $^{3} \cdot$ Jan Christian Habel ${ }^{4}$ D
}

Received: 8 July 2020 / Revised: 6 April 2021 / Accepted: 25 April 2021 /

Published online: 10 May 2021

(C) The Author(s) 2021

\begin{abstract}
Tropical forests suffer severe habitat destruction. Thus, tropical forests frequently consist today of only a few small remnants that are often embedded within a matrix of agricultural fields and tree plantations. Forest specialist species have experienced severe population declines under these circumstances. We studied bird communities based on census plots set up in a near-natural forest block, as well as degraded forest patches, tree plantations, and agricultural fields, across the Taita Hills in southern Kenya. We classified each bird species according its ecology and behavior. We quantified the land cover and landscape configuration around each census plot. Typical forest species were mainly observed in the near-natural forest block, and to a lower extent in degraded forest patches. Plantations were almost devoid of birds. Bird communities of small forest fragments were more similar to that of agricultural land than the near-natural forest block. Most frugivorous, insectivorous and nectarivorous birds occurred in forest habitats, while granivorous bird species dominated the bird communities of agricultural land. The surrounding landscape had a marginal impact on bird species composition at local sites. Our study showed that the preservation of near-natural cloud forest, including small forest patches, is essential for the conservation of forest-dependent species, and that plantations do not serve as surrogate habitats.
\end{abstract}

Keywords Birds · Cloud forest · Guilds · Habitat destruction · Surrogate habitat · Habitat quality

Communicated by Kwek Yan Chong.

This article belongs to the Topical Collection: Forest and plantation biodiversity.

Moses Mulwa

mulwamusa@gmail.com

1 Ornithology Section, Department of Zoology, National Museums of Kenya, P.O.

Box 40658-00100, GPO Nairobi, Kenya

2 Department of Geoecology, Institute of Geosciences and Geography, Martin Luther University Halle-Wittenberg, 06099 Halle (Saale), Germany

3 Department of Ecology and Biogeography, Nicolaus Copernicus University Toruń, 87-100 Toruń, Poland

4 Evolutionary Zoology, Department of Biosciences, University of Salzburg, 5020 Salzburg, Austria 


\section{Introduction}

A major driver leading to current biodiversity loss is the destruction of natural habitats and their transformations into agricultural land, settlements and plantations (Jantz et al. 2015; Maxwell et al. 2016). Tropical ecosystems are particularly affected by these threats, which are mainly driven by high human demographic pressure, weak governance structures and poor land management (Williams 2013; Nzau et al. 2020; Teucher et al. 2020). As a consequence, many remaining tropical ecosystems exist today as small and isolated remnants (Haddad et al. 2015) which provide comparatively low habitat quality (Sala et al. 2000; Wilkie et al. 2011). The destruction of habitats and the deterioration of habitat quality mostly result in a decrease of population size of species, and, as a consequence, these local populations often suffer population fluctuations, reduced population viability and low individual fitness (Reed and Frankham 2003; Melbourne and Hastings 2008).

Habitat destruction and the transformation of natural ecosystems into anthropogenic landscapes create surrogate habitats for many species (Greenler and Ebersole 2015). For example, clearing of natural forests and their transformation into plantations of exotic trees may provide surrogate habitats for species, including forest-dependent taxa (Berndt et al. 2008; Calviño-Cancela 2013). Or, the transformation of natural forest into settlements frequently includes the creation of gardens consisting of hedges, trees and flowers, and thus also provide suitable habitats for many species (Batáry et al. 2010; Heath et al. 2017; Wilson et al. 2017). In addition, the fragmentation of a formerly interconnected forest creates transition zones between forest patches and non-forest ecosystems that also provide valuable habitats for many species (Morante-Filho et al. 2018). However, such transformed and disturbed habitats are usually of lower habitat value for species depending on specific habitat conditions, and may even constitute ecological traps for some species (Barlow et al. 2007). Apart from habitat availability and habitat quality, the surrounding landscape may strongly impact the viability of populations, and thus shape species communities. Studies have shown that neighbouring ecosystems can have a greater effect on the local population than the quality of the corresponding habitat (Metzger 1997).

Species respond differently to environmental changes, such as habitat destruction and the deterioration of habitat quality (Bryce et al. 2002). Habitat specialists, such as species adapted to live in a dense and intact cloud forest, mostly occur exclusively in a specific habitat with specific resources. In consequence, specialist species are frequently restricted to still intact natural habitats and rarely use surrogate habitats, and do not live in small and isolated habitat fragments. Thus, species communities found across anthropogenic landscapes are frequently dominated by some few habitat generalist species (Kitahara and Fuji 1994; Abrahamczyk et al. 2008; Börschig et al. 2013).

In this study, we performed census counts on birds in Taita Hills in southern Kenya. The Taita Hills are part of the Eastern Afromontane biodiversity hotspot and host a unique flora and fauna (Mittermeier et al. 2011). The transformation of cloud forest into agricultural land and plantations of exotic trees led to an almost complete destruction of the original forest (Brooks et al. 1998; Lehouck et al. 2009). Today, the landscape of Taita Hills consists of a mosaic of settlements, agricultural fields, tree plantations and cloud forest patches. We analyzed bird communities across a fraction of the Taita Hills, including a near-natural forest, small forest fragments, plantations of exotic trees, and smallholder agricultural fields. We grouped bird species into guilds, according its ecology and behavior. We considered the land cover and landscape configuration around each census plot. Based on the results derived from our census counts we addressed the following questions: 
1. Do bird communities differ among habitat types, with respect to species and guild composition?

2. Do small and degraded forest fragments and plantations of exotic trees provide suitable surrogate habitats for forest-dependent birds?

3. Does the landscape around a local census plot affect bird species community structure and species diversity?

\section{Methods}

\section{Study area}

The Taita Hills in southern Kenya $\left(3^{\circ} 25^{\prime} \mathrm{S}, 38^{\circ} 20^{\prime} \mathrm{E}\right)$ consists of a mosaic of ecosystems, with near-natural forest blocks, small and degraded forest fragments, plantations of exotic trees (with representatives of the genus Pinus, Cypressus and Eucalyptus), agricultural land (crop fields with gardens), and settlements (Capitani et al. 2019; Teucher et al. 2020). The cloud forest cover of Taita Hills had been widely transformed into anthropogenic landscapes since the pre-colonial era (about 200 years ago), and continues until today, despite intense effort to protect the natural vegetation (Brooks et al. 1998; Lehouck et al. 2009; Teucher et al. 2020). The remaining natural cloud forest consists of 12 forest fragments, which differ in size (ranging from 1 to 200 ha), geographic isolation, and habitat quality (Lehouck et al. 2009; Callens et al. 2011). In our study, we selected the following four habitat types: 1. Near-natural cloud forest block (here Chawia forest), 2. Small and degraded forest fragments (here Fururu and Ndiwenyi forest patches), 3. Plantations of exotic trees, and 4. Agricultural fields. Chawia represents the third largest natural cloud forest in Taita Hills (Pellikka et al. 2009) with still largely intact plant species composition with Tabernaemontana stapfiana, Albizia gummifera, Phoenix reclinata and Macaranga conglomerata being the dominant tree species (Omoro et al. 2011). However, planting of exotic tree species across this forest patch has diminished its habitat quality (Wilder et al. 1998; Omoro et al. 2011). Fururu and Ndiwenyi represent two small and degraded forest fragments, which are interspersed with exotic trees such as eucalyptus, cypress and pine (Omoro et al. 2010). These forests are much more disturbed compared to the near-natural Chawia forest block. The selected tree plantations are pure stands of exotic tree species, such as woodlot with trunks with Acacia mearnsii, cypress or eucalyptus. Most of the undergrowth in these plantations was cleared, grazed, and/or burnt. The agricultural land are smallholder farms with fields of maize and beans. The geographic location of our study area with the habitat types and census plots set across the study area is shown in Fig. 1.

\section{Data collection}

In total, we set up 117 bird census plots across the four habitat types, with the following number per habitat type: Near-natural forest block Chawia (30 plots), degraded forest patches Fururu (18 plots) and Ndiwenyi (12 plots), plantations of exotic trees (26 plots), and agricultural land (21 plots). Plots were placed across the landscape, with minimum distances of at least $200 \mathrm{~m}$ between plots, to minimize potential effects from autocorrelation. In addition, each plot was set at least $50 \mathrm{~m}$ inside of each habitat type to reduce potential edge effects. Furthermore, plots were set at sites which were easily accessible (e.g. along 

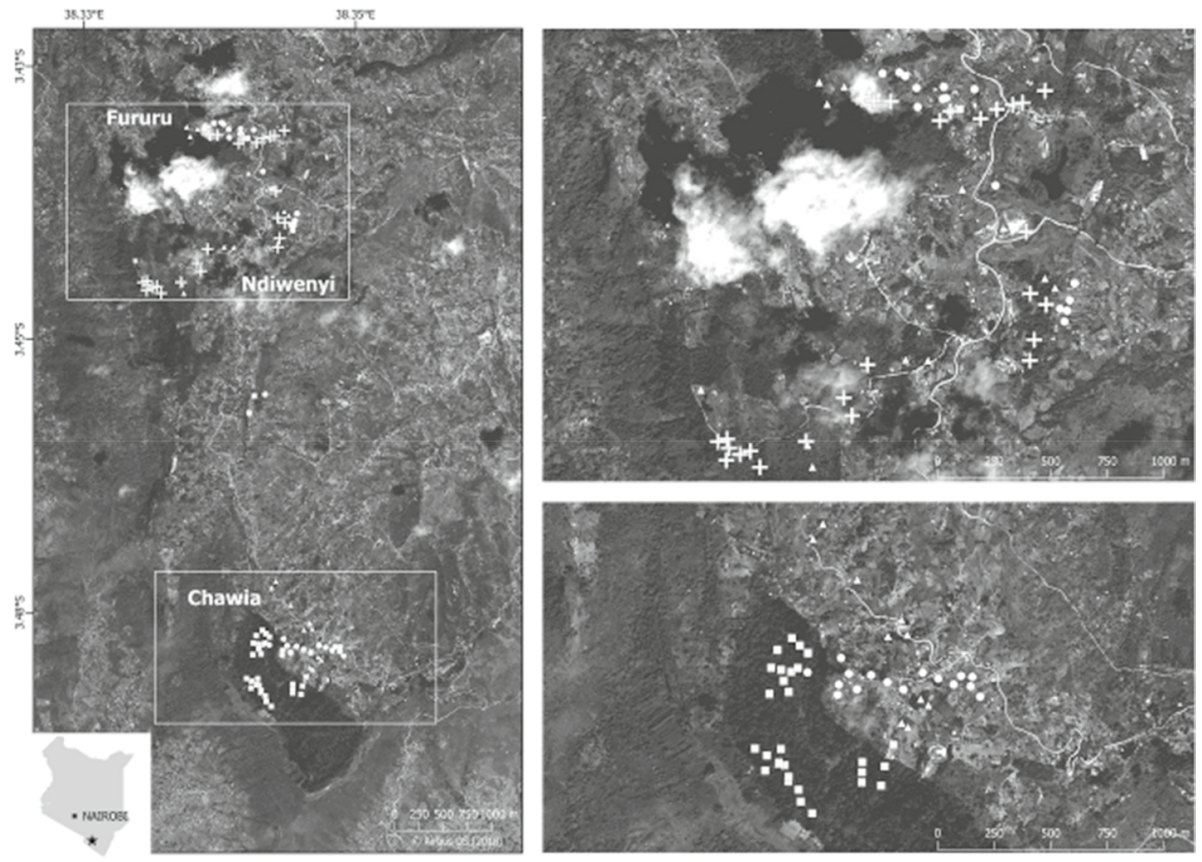

Fig. 1 The study area in Kenya (star in small inlet map), locations of census plots across the study area (left map) and the plot locations for study region Fururu and Ndiwenyi in the upper map and for Chawia in the bottom map on the right. Plots are indicated according to referencing habitat type for near-natural forest (square), degraded forest fragments (cross), agricultural land (circle), and plantations of exotic trees (triangle)

existing roads, tracks and paths, especially inside of the cloud forest block Chawia and in the two forest fragments). The distribution of all plots is displayed in Fig. 1.

We recorded birds at these plots during August 2018. Each bird count session lasted 10 min. Bird counts were performed during morning (between 7 and 10am) and afternoon (between 3:30 and $6 \mathrm{pm}$ ). We visited each plot at least three times, including morning and afternoon sessions for each plot (cf. Bibby et al. 1998, 2000). Bird recordings were performed during similar weather conditions (sunny to partly cloudy weather) and by the same team consisting of three ornithologists. The observers considered all birds within a radius of about $50 \mathrm{~m}$, but excluded birds which were flying over the plot. Most bird individuals were identified to species level based on calls and visual observation (cf. Bibby et al. 1998, 2000). The consideration of bird calls reduces potential biases from higher visual detectability in open landscapes than in dense cloud forests (Kellner and Swihart, 2014). The complete list of all bird species observed including the number of individuals assessed is given in Appendix S1

\section{Guilds}

We grouped all birds observed into guilds, according to their diet and habitat preference (i.e. forest-dependency). We considered the following diet classes according to the major food source: raptors, insectivores, nectarivores, granivores, frugivores, and omnivores 
(Kissling et al. 2007). Dietary items for all recorded birds were referenced from Kissling et al. (2007), by considering the major food item for each bird species. Dietary preferences may strongly shape bird assemblages (see Githiru et al. 2005). We grouped species according habitat preferences as follows: forest specialists (i.e., forest interior species), forest generalists (i.e., also found in gardens and shrubs beyond the forest), savannah species/forest visitors, and non-forest species (i.e., occurring mainly in open landscapes) (Bennun et al. 1996). Guild classification is compiled in Appendix S1.

\section{Land cover analyses}

Land cover assessment was conducted based on multispectral satellite imagery of the SPOT series (Centre National d'Etudes Spatiales 2015). We used SPOT 7 images, with a 6-m geometric resolution and 4-band spectral resolution (blue, green, red and NIR). These satellite images were taken during October 2018. The images were radiometrically corrected using the Geosud ToA Reflectance Plugin within QGIS (Ose 2015). Initial land cover classification was done using the semi-automatic classification plugin for QGIS (Congedo 2016). Further details on the procedure are given in Teucher et al. (2020). We considered the following land cover categories (according to the FAO Land Cover Classification System, Di Gregorio (2016), not identical with the naming of the habitat types used in this study so far): Indigenous forest (hereafter referring to natural forest), mixed forest (i.e. natural forest mixed with exotic trees), exotic tree plantation, bushland/shrubland/ woodland (hereafter referred as bushland), cropland, built-up area and bare soil/rock and other unconsolidated material, and grassland. The classes 'cloud' and 'cloud shadow' were assigned to the class 'unclassified' $\left(1.89 \mathrm{~km}^{2}, 1.73 \%\right.$ only). Classification accuracy was assessed with an error matrix and Kappa statistics (Monserud and Leemans 1992; Pontius 2000). We achieved an overall accuracy of $80.7 \%$ according ground truthing data, expert knowledge and inspection of Google Earth images. Due to the fact that the neighbouring habitats and the surrounding landscape structure (e.g. heterogeneity and connectedness) strongly impact and shape species community structures in a habitat and can have even greater effects on a local population than the quality of the habitat (Metzger 1997; Mitchell et al. 2006), we considered data on adjoining land cover (within a 50-m circle) and the surrounding landscape structure (within a 1000-m circle). Thus, we calculated the proportional share of each land cover category using the zonal statistics function in QGIS for a 50 - $\mathrm{m}$ circular buffer around each plot. For a 1000-m circular buffer we calculated the landscape configuration with the program Fragstats 4.2 (McGarigal 2015). Here we considered the following metrics: 1 . Clumpiness index (landscape texture/aggregation in terms of the spatial intermixing of different land cover categories); 2. Standard deviation of the clumpiness index (a measure of variability); and, 3. Patch cohesion index (measure of the physical connectedness of the land cover categories). Further details on landscape configuration and composition can be found in Teucher et al. (2020). Details on land cover and landscape configuration for each plot are provided in Appendix S2.

\section{Statistics}

To infer habitat specific differences in species richness and abundances of bird feeding and habitat guilds we used general linear modelling (GLM) analysis with habitat types as predictors and abundance and numbers of species as response variables. Additional response variables were the first and second dominant eigenvectors of a principle coordinates 
analysis (Bray-Curtis dissimilarities) applied to the 65 species $\times 117$ plots abundance matrix. These eigenvectors captured the variability in community structure among the habitat types. In a second GLM analysis, landscape features (clumpiness, SD of clumpiness, and connectivity) served as predictors. Predictors and response variables were only moderately intercorrelated (Appendix S3). Canonical correspondence analysis in combination with two-way Permanova (using Bray-Curtis dissimilarity) served to infer differences in bird community composition among habitat categories and study sites. We used t-tests for simple pairwise comparisons. We identified habitat specific bird guilds using correspondence analysis (seriation) in combination with k-means clustering. Calculations were done with Statistica 12.0.

\section{Results}

In total, we recorded 2,221 bird individuals, which belong to 65 bird species (Table 1). Plots in disturbed forest fragments and agricultural land provided highest species richness (Table 1). Agricultural land and near-natural forest (Chawia) yielded the highest number of individuals (Table 1). However, the average numbers of species per plot did not significantly differ between near-natural forest (Chawia), the forest fragments (Fururu and Ndiwenyi) and agricultural land (Table 1). In turn, bird abundances of plots in the agricultural land were significantly higher $(\mathrm{t}$-test $\mathrm{P}<0.01)$ than in the near-natural forest and the forest fragments (Table 1). In the plantations, only two individuals of the Chin-spot Batis (Batis molitor), a cooperative breeding insectivore bird species, were recorded. All other birds found there were flying over and thus were not considered in our analyses.

When classifying birds according to their feeding guilds, frugivores and insectivores achieved the highest average abundances in near-natural forest (Fig. 2a). Granivores and nectarivores dominated in the agricultural landscape (Fig. 2a), and insectivores and frugivores reached highest abundances in the forest fragments (Fig. 2a). The agricultural landscape was highly dominated by forest visitors, while forest specialists and generalists dominated in the near-natural forest (Fig. 2b). The forest fragments were evenly inhabited by all four habitat guilds (ANOVA: P >0.05; Fig. 2b).

Two-way Permanova revealed significant differences in bird community composition between the three habitat types (excluding plantations) and the three study sites (Table 2). Of the 65 species, 28 (43.1\%) were habitat specific (Fig. 3). Nevertheless, as much as 18 species occurred in all three habitat types (near-natural forest, degraded forest fragments, and agricultural land, Fig. 3). A high compositional similarity also occurred between the

Table 1 Basic richness and abundance data. Given are number of sites, species richness (total and mean $( \pm \mathrm{SD})$ ), and abundance (total and mean $( \pm \mathrm{SD})$ ) according to the three habitat types studied

\begin{tabular}{|c|c|c|c|c|c|}
\hline \multirow[t]{2}{*}{ Habitat } & \multirow[t]{2}{*}{$N$ sites } & \multicolumn{2}{|c|}{ Species richness } & \multicolumn{2}{|c|}{ Abundance } \\
\hline & & Total & Average & Total & Average \\
\hline Agricultural land & 34 & 41 & $8.2 \pm 0.9$ & 998 & $29.4 \pm 3.1$ \\
\hline Near-natural forest & 33 & 34 & $8.2 \pm 0.5$ & 749 & $22.7 \pm 2.6$ \\
\hline Forest fragments & 28 & 45 & $8.1 \pm 0.6$ & 472 & $16.9 \pm 2.4$ \\
\hline Plantations & 22 & 1 & $0.1 \pm 0.1$ & 2 & $0.1 \pm 0.1$ \\
\hline Sum & 117 & 65 & $6.6 \pm 0.4$ & 2221 & $19.0 \pm 1.6$ \\
\hline
\end{tabular}

Errors refer to standard errors 

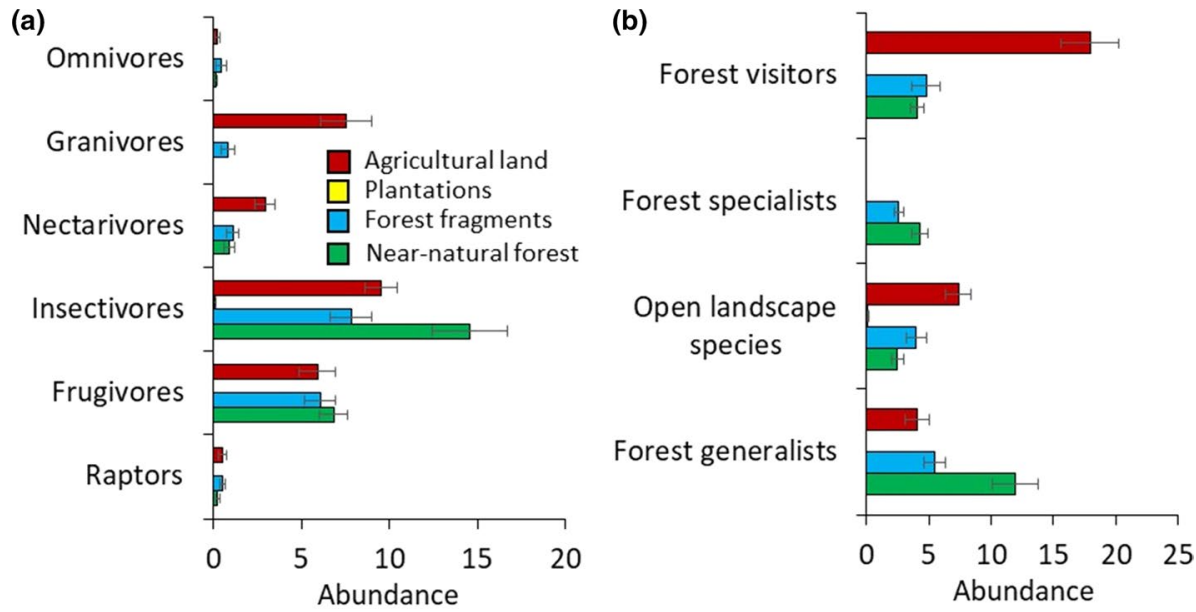

Fig. 2 Average abundances ( \pm standard error) of six feeding guilds (a) and four life history types among four studied habitats within the 117 plots

Table 2 Two-way Permanova (Soerensen dissimilarity) detected significant differences in bird community composition between study sites (Ndiwenyi, Fururu, Chawia) and three habitat type (natural forest, forest fragments, and agricultural land)

\begin{tabular}{lllcc}
\hline Variable & df & Mean square & F & p \\
\hline Site & 2 & 0.72 & 1.25 & $<0.001$ \\
Habitat & 2 & 2.83 & 4.95 & $<0.001$ \\
Interaction & 4 & 6.07 & 10.60 & 0.08 \\
Residual & 86 & & & \\
\hline
\end{tabular}

agricultural sites and the forest fragments (Fig. 3). A substantial number of forest generalists and forest visitors were present in all three habitat types (Fig. 3). Forest specialists were not seen in open agricultural landscapes (Fig. 3). Interestingly, 5 out of the 19 open landscape species were only recorded in the forest (Fig. 3). Correspondence analysis identified four major groups of habitat preferences (Appendix S3, Figs. A1, A2). Two of these groups with 17 and 15 species, respectively, consist of pure and partial open landscape dwellers, the latter with occasional occurrences in the forest fragments and the near-natural forest (Appendix S3). A third group of 26 species are true habitat generalists (Appendix S3, Fig. A1). Only nine species are true forest specialists (Appendix S3, Fig. A1). Canonical correspondence analysis ordered the bird feeding and habitat guilds along the dominant axis that correlated with the gradient from near-natural forest to agricultural open landscape (Appendix S3, Fig. A2).

Finally, we analyzed potential effects of land cover type and land configuration to bird species richness, abundance and community composition (Table 3). We found a moderate negative correlation of the percentage of mixed forest with overall bird abundances (Table 3). The percentage of forest was positively linked to bird species richness (Table 3). Further, the pairs of forest and percentage of building, and of forest and agricultural land had opposite effects on community structure (Table 3). The variability in habitat 

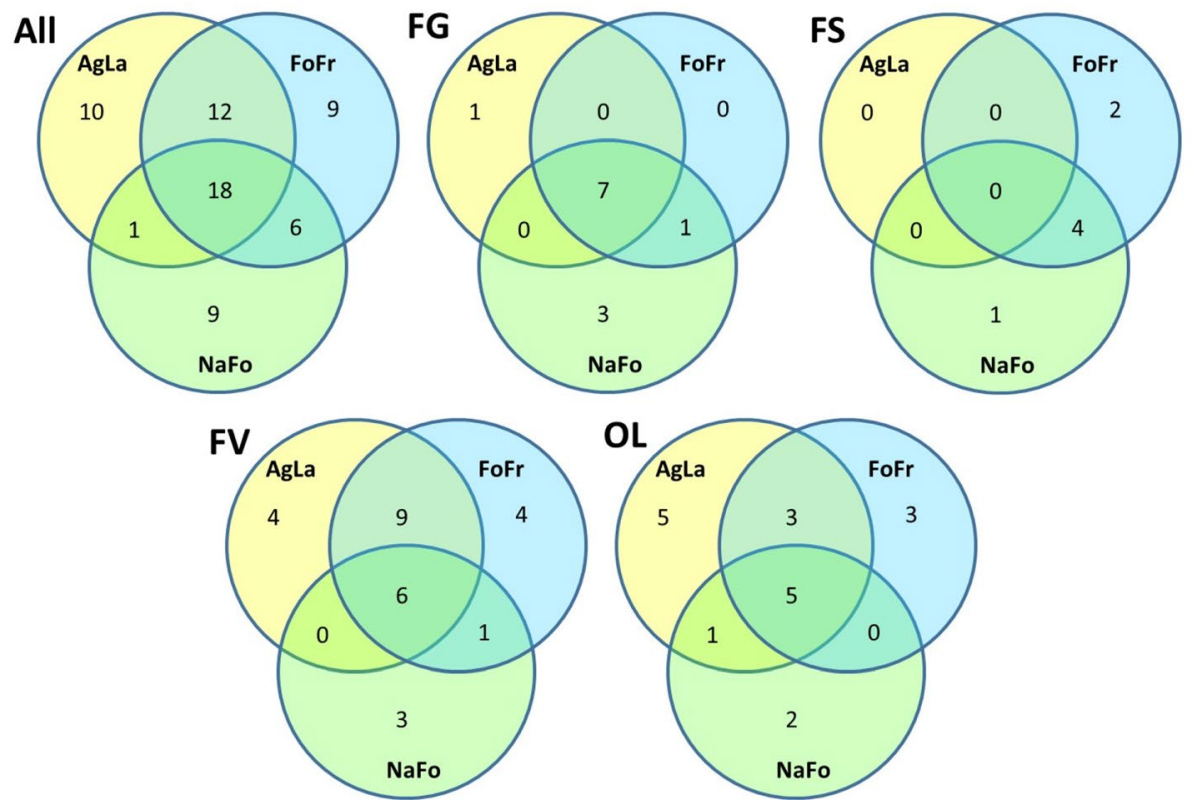

Fig. 3 Venn diagrams showing numbers of all species (All), forest generalists (FG), forest specialist (FS), forest visitors (FV), and open landscape species (OL) shared by three of the four studied habitat types (NaFo: Near-natural forest, FoFr: Forest fragments, AgLa: Agricultural land)

Table 3 General linear model using habitat cover percentages and landscape clumping, respective standard deviation $S D$ of clumping, and connectivity as predictors for bird abundance, richness, and community composition as quantified by the first two Eigenvectors of a principle coordinates analysis (Bray Curtis dissimilarity) of the species $\times$ plot matrix. (PCoA 1: $20.0 \%$ of variance, PCoA 2: $8.6 \%$ of variance)

\begin{tabular}{lllll}
\hline Habitat & Abundance & Species richness & PCoA 1 & PCoA 2 \\
\hline Indigenous & $0.21 \pm 0.17$ & $0.44 \pm 0.17^{*}$ & $0.42 \pm 0.17^{*}$ & $-0.35 \pm 0.11^{* *}$ \\
Exotic forest & $0.29 \pm 0.14$ & $0.04 \pm 0.14$ & $-0.15 \pm 0.14$ & $0.12 \pm 0.09$ \\
Mixed forest & $-0.29 \pm 0.12^{*}$ & $-0.13 \pm 0.13$ & $-0.21 \pm 0.12$ & $-0.11 \pm 0.08$ \\
Bushland & $0.16 \pm 0.16$ & $0.15 \pm 0.17$ & $0.15 \pm 0.16$ & $0.25 \pm 0.11^{*}$ \\
Cropland & $0.12 \pm 0.19$ & $0.16 \pm 0.19$ & $0.05 \pm 0.18$ & $0.54 \pm 0.12^{* * *}$ \\
Buildings & $-0.03 \pm 0.14$ & $-0.21 \pm 0.14$ & $-0.36 \pm 0.14^{*}$ & $-0.07 \pm 0.09$ \\
Grassland & $0.17 \pm 0.15$ & $0.21 \pm 0.15$ & $0.04 \pm 0.14$ & $-0.14 \pm 0.09$ \\
$\mathrm{r}^{2}$ & $0.21^{* *}$ & $0.19^{*}$ & $0.25^{* *}$ & $0.69^{* * *}$ \\
Clumpiness & $-0.31 \pm 0.23^{*}$ & $-0.03 \pm 0.22$ & $0.21 \pm 0.22$ & $-0.62 \pm 0.22^{*}$ \\
SD clumpiness & $-0.20 \pm 0.20$ & $-0.51 \pm 0.19 * *$ & $-0.63 \pm 0.19^{* *}$ & $0.44 \pm 0.18^{*}$ \\
Cohesion & $-0.05 \pm 0.31$ & $0.47 \pm 0.30$ & $0.76 \pm 0.30^{*}$ & $0.16 \pm 0.29$ \\
$\mathrm{r}^{2}$ & 0.07 & $0.10^{*}$ & $0.13^{*}$ & $0.19^{* *}$ \\
\hline
\end{tabular}

Given are beta values, respective standard errors and the examined variance $\left(\mathrm{r}^{2}\right)$ of the whole model. Parametric significances: $* \mathrm{P}<0.05 ; * * \mathrm{P}<0.01, * * * \mathrm{P}<0.001$ 
clumpiness was negatively correlated with species richness and also affected the composition of the bird species community (Table 3 ).

\section{Discussion}

We found differences in bird species richness and community structure among the four habitat types. Disturbed forest fragments and the agricultural land provided higher species richness than the near-natural forest block and plantations of exotic trees. The composition of the bird species communities was relatively similar in the degraded forest fragments and the surrounding agricultural land, while the bird community composition found in the near-natural forest block diverged considerably, where forest-dependent bird species occur in comparatively high densities. In the following we will discuss 1 . The value of large nearnatural forest blocks; 2 . The relevance of forest fragments and plantations as potential habitat surrogates for forest species; and 3. The role of the environment in which habitats are embedded.

\section{The value of large and near-natural forest}

Nine out of the 65 bird species observed were exclusively found in the near-natural forest block, Chawia. A closer examination of species composition across the four studied habitat types indicated that forest specialists are mainly found in the near-natural forest block, and did not occur in open agricultural land and only rarely colonize degraded forest fragments (although possibly as temporary visitors rather than as permanent residents). For example, the Sharpe's Starling Cinnyricinclus sharpii is a scarce forest specialist of the Afrotorpical highland biome (Bennun and Njoroge 1999) that relies on fruiting forest trees (Lewis and Pomerory 1989). This regionally near-threatened species (Brooks et al. 1998) was exclusively observed in the interior of the large near-natural forest block, Chawia, but was not found in the small and degraded forest fragments.

Our data revealed further differences in bird species community structures. Frugivores and insectivores were found in the near-natural forest block Chawia, while granivorous bird species dominated the bird species community in the agricultural land. The degraded forest fragments supported frugivores and insectivores, with less of forest-dependent guilds. Previous studies on bird species community structures in Taita Hills forest fragments underline that the abundance of bird species with a broad variety of food demands (insectivores, frugivores, nectarivores) are frequently rare in fragments with low habitat quality, while omnivore bird species remained stable across all forest fragments, irrespective of the degree of habitat quality (Ulrich et al. 2016). In conclusion, large near-natural forest blocks are of relevance to maintain forest-dependent bird species, requiring specific forest resources and habitat pre-conditions.

\section{Diversity in small and disturbed forest patches}

Our study showed higher bird species richness for small and disturbed forest fragments and agricultural land if compared with the near-natural forest block. This goes in line with other studies indicating higher bird species diversity in disturbed habitats than in rather intact ones (Fischer and Lindenmayer 2002; Woltmann 2003; Bett et al. 2016). These differences in species richness between disturbed and intact habitats are 
primarily attributed to the additional occurrence of widespread species in disturbed habitats (Kitahara and Fujii 1994; Börschig et al. 2013; but also see Lenda et al. 2012; Tropek et al. 2013 for opposite relationships). Similarly, transition zones between two habitat types, such as forest edges, are often richer in species than the interior of an intact forest (Habel et al. 2018). This is due to the fact that transition ecotones as well as disturbed (forest) habitat fragments mostly provide a larger variety of ecological niches and resources, and might become colonized from both forest and open-land dwelling species.

Our study showed that forest-dependent birds also occurred in small and degraded forest fragments, but in lower abundances. This could mean either that at least some habitat specialists are still able to survive in disturbed habitats, or that forest specialist species are visitors of small forest patches. However, small and isolated forest fragments are generally considered as having reduced habitat quality, and might not sustain rich communities for longer time (Ulrich et al. 2016). Despite the fact that the forest fragments do not harbour some of the forest-dependent bird species and show divergent forest community structure if compared with the bird species community of the near natural Chawia forest block (see also Simberloff and Abele 1976; Muwal et al. 2012), these smaller fragments may serve as important stepping stones. This allows species to migrate among three larger forest blocks across Taita Hills (see Pellikka et al. 2009) and thus enhance the opportunity for biotic exchange and the persistence of species at the landscape level (Blake and Karr 1984).

\section{Anthropogenic surrogate habitats for forest species}

We found very low bird species richness and abundance in the plantations of exotic trees. All plantations assessed in this study were stands of adult Acacia mearnsii, eucalyptus and cypress species. The undergrowth was mainly used for cattle grazing, and the harvested wood as an energy source (i.e., firewood) and for housing construction. Thus, the plantations were mostly very light and without a shrub layer. The lack of plant undercover and flowering plants might lead to a rather low number of insects. As a consequence, such habitat structures exclude frugivorous, granivorous and nectarivorous bird species. Previous studies showed that bird species richness and abundances in plantations (versus natural forest) is strongly driven by local and temporal food availability (Mitra and Sheldon 1993). In contrast to our results, other studies have shown that tree plantations, even when consisting of a single exotic tree species, can provide a suitable habitat for forest species (Dent and Wright2009; Castano-Villa et al. 2019) and thus act as important surrogate habitat, which become relevant in regions suffering under high rates of deforestation and forest degradation (e.g. the Taita Hills). Thus, there is a controversial debate on the ecological value of tree plantations for (forest) species (Marsden et al. 2001; Berndt et al. 2008; Farwig et al. 2008; Calviño-Cancela 2013). The ecological value of plantations can be significantly improved by an increase of habitat heterogeneity through planting of native plant species undergrowth (Hartley 2002; Nájera and Simonetti 2010). However, this is completely lacking in our study sites. Given that the plantations and small forest patches only hold a small proportion of species richness and abundance of forest-dependent species, it remains questionable to what extent the unique biodiversity of Taita Hills can be preserved in the long term, as only three larger forest blocks are left (Lens et al. 2002). 


\section{Impacts from the surrounding environment}

We found that the effects of the land cover around a census plot on bird species richness and diversity were of only little relevance. Less habitat clumpiness was positively correlated with species richness, and also affected the composition of the bird species community significantly. Clumpiness quantifies landscape texture in terms of the spatial intermixing of different land cover categories. More habitat clumpiness means more like adjacencies in the landscape, higher connectivity within habitats and less habitat heterogeneity. In turn, less clumpiness (i.e. increasing habitat composition and/ or configuration in the landscape, and more disturbance) is associated with higher species richness and population persistence. This goes in line with other studies analysing landscape configuration (e.g. clumpiness) and biodiversity (see Olsoy et al. 2016). The effect caused by the surrounding environment could be due to the fine-grained mosaic landscape structure in combination with the comparatively high mobility of birds.

\section{Caveats}

As any comparative study, ours might be affected by various shortcomings that could limit the significance of our results and conclusions:

1. Study duration: Our surveys were conducted within a short period of time, and seasonal fluctuations might significantly change the spatial distribution of bird species (see Mulwa et al. 2013).

2. Limited sample size and restricted sample coverage: Our study represents the situation only for a very restricted area within the Taita Hills. Therefore, the generality of these results and correlations obtained should be considered with caution.

3. Autocorrelation: At the regional scale, habitat types are not randomly distributed, but occur clustered depending on land use and soil features. Consequently, any comparison of habitat types might be affected from spatial non-independence of data points (Hawkins 2012).

4. Diverging detectability in different habitat types: Lower species richness in near-natural forest could have been the result of under-detection of birds due to high vegetation density or tree heights in near-natural forest compared to disturbed forest fragments and agricultural land, and also because of forest specialist species tend to occur in lower densities than generalist species. We partially countered this bias by including bird calls in addition to visual observations (cf. Bibby et al. 1998, 2000).

Supplementary Information The online version contains supplementary material available at https://doi. org/10.1007/s10531-021-02190-y.

Acknowledgements We thank Kioko Mukua and Ednah Kulola (National Museums of Kenya, NMK) for their help during data collection. This study was conducted in close collaboration with the National Museums of Kenya, Ornithology Section. We thank the German Academic Exchange Service DAAD for funding this activity. W.U. acknowledges funding from an internal NCU grant within the Polish excellence initiative (IDUB). We are grateful for very valuable comments by Beate Apfelbeck (Salzburg, Austria) and three anonymous reviewers and the subject editor on a draft of this article. 
Author contributions $\mathrm{JCH}$ and MT designed the study, MM led the collection of the data in the field, WU did the statistics, all contributed while writing.

Funding Open access funding provided by Paris Lodron University of Salzburg. This study was supported by the German Academic Exchange Service, DAAD.

Data availability All raw data are provided as supplementary material.

\section{Declarations}

Conflicts of interest There exists no conflicts of interests/no competing interests.

Consent to participate All authors gave consent to participate.

Consent for publication All authors gave consent for publication.

Open Access This article is licensed under a Creative Commons Attribution 4.0 International License, which permits use, sharing, adaptation, distribution and reproduction in any medium or format, as long as you give appropriate credit to the original author(s) and the source, provide a link to the Creative Commons licence, and indicate if changes were made. The images or other third party material in this article are included in the article's Creative Commons licence, unless indicated otherwise in a credit line to the material. If material is not included in the article's Creative Commons licence and your intended use is not permitted by statutory regulation or exceeds the permitted use, you will need to obtain permission directly from the copyright holder. To view a copy of this licence, visit http://creativecommons.org/licenses/by/4.0/.

\section{References}

Abrahamczyk S, Kessler M, Dwi Putra D, Waltert M, Tscharntke T (2008) The value of differently managed cacao plantations for forest bird conservation in Sulawesi Indonesia. Bird Conserv Int 18:349

Barlow J, Gardner TA, Araujo IS, Avila-Pires TC, Bonaldo AB, Costa JE, Peres CA (2007) Quantifying the biodiversity value of tropical primary, secondary, and plantation forests. Proc Natl Acad Sci 104:18555-18560

Batáry P, Matthiesen T, Tscharntke T (2010) Landscape-moderated importance of hedges in conserving farmland bird diversity of organic vs. conventional croplands and grasslands. Biol Cons 143:2020-2027

Bennun L, Dranzoa C, Pomeroy D (1996) The forest birds of Kenya and Uganda. J East Afr Nat Hist $85: 23-48$

Bennun LA, Njoroge P (1999) Important bird areas in Kenya. Nature Kenya, East Africa Natural History Society, Nairobi

Berndt LA, Brockerhoff EG, Jactel H (2008) Relevance of exotic pine plantations as a surrogate habitat for ground beetles (Carabidae) where native forest is rare. Biodivers Conserv 17:1171-1185

Bett MC, Muchai M, Waweru C (2016) Avian species diversity in different habitat types in and around North Nandi Forest, Kenya. Afr J Ecol 54:341-348

Bibby C, Jones M, Marsden S (1998) Expedition field techniques: bird surveys. Expedition Advisory Centre, Royal Geographical Society, London

Blake JG, Karr JR (1984) Species composition of bird communities and the conservation benefit of large versus small forests. Biol Cons 30:173-187

Börschig C, Klein A-M, von Wehrden H, Krauss J (2013) Traits of butterfly communities change from specialist to generalist characteristics with increasing land-use intensity. Basic Appl Ecol 14:547-554

Brooks T, Lens L, Barnes J, Barnes R, Kihuria JK, Wilder C (1998) The conservation status of the forest birds of the Taita Hills, Kenya. Bird Conserv Int 8:119-139

Bryce SA, Hughes RM, Kaufmann PR (2002) Development of a bird integrity index: Using bird assemblages as indicators of riparian condition. J Environ Manage 30:294-310

Callens T, Galbusera P, Matthysen E, Durand EY, Githiru M, Huyghe JR, Lens L (2011) Genetic signature of population fragmentation varies with mobility in seven bird species of a fragmented Kenyan cloud forest. Mol Ecol 20:1829-1844 
Calviño-Cancela M (2013) Effectiveness of eucalypt plantations as a surrogate habitat for birds. J For Ecol Manag 310:692-699

Capitani C, Garedew W, Mitiku A, Berecha G, Hailu BT, Heiskanen J, Marchant R (2019) Views from two mountains: exploring climate change impacts on traditional farming communities of Eastern Africa highlands through participatory scenarios. J Sustain Sci 14:191-203

Castaño-Villa GJ, Estevez JV, Guevara G, Bohada-Murillo M, Fontúrbel FE (2019) Differential effects of forestry plantations on bird diversity: a global assessment. J For Ecol Manage 440:202-207

Centre National d'Etudes Spatiales (2015) Spot 2015. retrieved from https://spot.cnes.fr/en/SPOT/index.htm

CJ (ed.) (2000) Bird census techniques (2nd ed). London ; San Diego: Academic

Congedo L (unpublished). Semi-automatic classification plugin documentation (Version Release 6.0.1.1.).

Dent DH, Joseph Wright S (2009) The future of tropical species in secondary forests: a quantitative review. Biol Cons 142:2833-2843

Di Gregorio A (2016) Land cover classification system. Classification concepts (Version Software version). Rome.

Farwig N, Sajita N, Böhning-Gaese K (2008) Conservation value of forest plantations for bird communities in western Kenya. For Ecol Manage 255:3885-3892

Fischer J, Lindenmayer DB (2002) Small patches can be valuable for biodiversity conservation: two case studies on birds in southeastern Australia. Biol Cons 106:129-136

Githiru M, Bennun L, Lens L, Ogol C (2005) Spatial and temporal variation in fruit and fruit-eating birds in the Taita Hills, south-east Kenya. Ostrich 76:37-44

Greenler SM, Ebersole JJ (2015) Bird communities in tropical agroforestry ecosystems: an underappreciated conservation resource. Agrofor Syst 89:691-704

Habel JC, Seibold S, Ulrich W, Schmitt T (2018) Seasonality overrides differences in butterfly species composition between natural and anthropogenic forest habitats. Anim Conserv 21:405-413

Haddad NM, Brudvig LA, Clobert J, Davies KF, Gonzalez A, Holt RD, Townshend JR (2015) Habitat fragmentation and its lasting impact on Earth's ecosystems. Sci Adv 1:e1500052

Hartley MJ (2002) Rationale and methods for conserving biodiversity in plantation forests. J For Ecol Manag 155:81-95

Hawkins BA (2012) Eight (and a half) deadly sins of spatial analysis. J Biogeogr 39:1-9

Heath SK, Soykan CU, Velas KL, Kelsey R, Kross SM (2017) A bustle in the hedgerow: woody field margins boost on farm avian diversity and abundance in an intensive agricultural landscape. Biol Cons 212:153-161

Jantz SM, Barker B, Brooks TM, Chini LP, Huang Q, Moore RM, Hurtt GC (2015) Future habitat loss and extinctions driven by land-use change in biodiversity hotspots under four scenarios of climatechange mitigation: future habitat loss and extinctions. Conserv Biol 29:1122-1131

Kellner KF, Swihart RK (2014) Accounting for imperfect detection in ecology: a quantitative review. PLoS ONE 9:e111436

Kissling WD, Rahbek C, Böhning-Gaese K (2007) Food plant diversity as broad-scale determinant of avian frugivore richness. Proc R Soc B 274:799-808

Kitahara M, Fujii K (1994) Biodiversity and community structure of temperate butterfly species within a gradient of human disturbance: an analysis based on the concept of generalist vs. Spec Strateg Res Popul Ecol 36:187-199

Lehouck V, Spanhove T, Demeter S, Groot NE, Lens L (2009) Complementary seed dispersal by three avian frugivores in a fragmented Afromontane forest. J Veget Sci 20:1110-1120

Lenda M, Skórka P, Moroń D, Rosin ZM, Tryjanowski P (2012) The importance of the gravel excavation industry for the conservation of grassland butterflies. Biol Cons 148:180-190

Lens L, Van Dongen S, Norris K, Githiru M, Matthysen E (2002) Avian persistence in fragmented rainforest. Science 298:1236-1238

Lewis A, Pomeroy D (1989) A bird atlas of Kenya. Rotterdam/Brookfield

Marsden SJ, Whiffin M, Galetti M (2001) Bird diversity and abundance in forest fragments and Eucalyptus plantations around an Atlantic forest reserve, Brazil. Biodivers Conserv 10:737-751

Maxwell SL, Fuller RA, Brooks TM, Watson JEM (2016) Biodiversity: the ravages of guns, nets and bulldozers. Nature 536:143-145

McGarigal K (2015) Fragstats help. Retrieved from https://www.umass.edu/landeco/research/fragstats/ documents/fragstats.help.4.2.pdf.

Melbourne BA, Hastings A (2008) Extinction risk depends strongly on factors contributing to stochasticity. Nature 454:100-103

Metzger JP (1997) Relationships between landscape structure and tree species diversity in tropical forests of South-East Brazil. Landsc Urban Plan 37:29-35 
Mitchell MS, Rutzmoser SH, Wigley B, Loehle C, Gerwin JA, Keyser PD, Lancia RA, Perry RW, Reynolds CJ, Thili RE, Weih R, White D, Wood PB (2006) Relationships between avian richness and landscape structure at multiple scales using multiple landscapes. For Ecol Manage 221:155-169

Mitra SS, Sheldon FH (1993) Use of an exotic tree planation by Bornean lowland forest birds. Auk 110:529-540

Mittermeier RA, Turner WR, Larsen FW, Brooks TM, Gascon C (2011) Global biodiversity conservation: the critical role of hotspots. In: Zachos F, Habel J (eds) Biodiversity hotspots. Springer, Berlin

Monserud RA, Leemans R (1992) Comparing global vegetation maps with the Kappa statistic. Ecol Model 62:275-293

Morante-Filho JC, Arroyo-Rodríguez V, de Pessoa M, S, Cazetta E, Faria D, (2018) Direct and cascading effects of landscape structure on tropical forest and non-forest frugivorous birds. Ecol Appl 28:2024-2032

Mulwa RK, Neuschulz EL, Böhning-Gaese K, Schleuning M (2013) Seasonal fluctuations of resource abundance and avian feeding guilds across forest-farmland boundaries in tropical Africa. Oikos 122:524-532

Muwal RK, Böhning-Gaese K, Schleuning M (2012) High bird species diversity in structurally heterogeneous farmland in Western Kenya. Biotropica 44:801-809

Nájera A, Simonetti JA (2010) Enhancing avifauna in commercial plantations. Conserv Biol 24:319-324

Nzau JM, Gosling E, Rieckmann M, Shauri H, Habel JC (2020) The illusion of participatory forest management success in nature conservation. Biodivers Conserv 29:1923-1936

Olsoy PJ, Zeller KA, Hicke JA, Quigley HB, Rabinowitz AR, Thornton DH (2016) Quantifying the effects of deforestation and fragmentation on a range-wide conservation plan for jaguars. Biol Cons 203:8-16

Omoro Loice MA, Laiho R, Starr M, Pellikka PKE (2011) Relationships between native tree species and soil properties in the indigenous forest fragments of the Eastern Arc Mountains of the Taita Hills, Kenya. Forest Stud China 13:198-210

Omoro Loice MA, Pellikka PKE, Rogers PC (2010) Tree species diversity, richness, and similarity between exotic and indigenous forests in the cloud forests of Eastern Arc Mountains, Taita Hills, Kenya. J Forest Res 21:255-264

Ose K (2015) QGIS python plugins repository. Irstea.

Pellikka PKE, Lötjönen M, Siljander M, Lens L (2009) Airborne remote sensing of spatiotemporal change (1955-2004) in indigenous and exotic forest cover in the Taita Hills, Kenya. Int J Appl Earth Observ Geoinform 11:221-232

Pontius RG (2000) Quantification error versus location error in comparison of categorical maps. Photogram Remote Sens 66:1011-1016

Reed DH, Frankham R (2003) Correlation between fitness and genetic diversity. Conserv Biol 17:230-237

Sala OE (2000) Global biodiversity scenarios for the year 2100. Science 287:1770-1774

Simberloff DS, Abele LG (1976) Island biogeography theory and conservation practice. Science 191:285-286

Spot 2015. Retrieved from https://spot.cnes.fr/en/SPOT/index.htm.

Teucher M, Schmitt CB, Wiese A, Apfelbeck B, Maghenda M, Pellikka P, Habel JC (2020) Behind the fog: Forest degradation despite logging bans in an East African cloud forest. Global Ecol Conserv 22:e01024

Tropek R, Cerna I, Straka J, Cizek O, Konvicka M (2013) Is coal combustion the last chance for vanishing insects of inland drift sand dunes in Europe? Biol Cons 162:60-64

Ulrich W, Lens L, Tobias JA, Habel JC (2016) Contrasting patterns of species richness and functional diversity in bird communities of East African cloud forest fragments. PLoS ONE 11:e0163338

Wilder C, Brooks T, Lens L (1998) Vegetation structure and composition of the Taita Hills forests. J East Afr Nat Hist 87:181-187

Wilkie DS, Bennett EL, Peres CA, Cunningham AA (2011) The empty forest revisited. Ann NY Acad Sci 1223:120-128

Williams JN (2013) Humans and biodiversity: population and demographic trends in the hotspots. Popul Environ 34:510-523

Wilson S, Mitchell GW, Pasher J, McGovern M, Hudson M-AR, Fahrig L (2017) Influence of crop type, heterogeneity and woody structure on avian biodiversity in agricultural landscapes. Ecol Ind 83:218-226

Woltmann S (2003) Bird community responses to disturbance in a forestry concession in lowland Bolivia. Biodivers Conserv 12:1921-1936

Publisher's Note Springer Nature remains neutral with regard to jurisdictional claims in published maps and institutional affiliations. 